\title{
François-René de Chateaubriand, Viaggio in America
}

\section{Gaudenzio Boccazzi}

\section{(2) OpenEdition}

\section{Journals}

\section{Edizione digitale}

URL: http://journals.openedition.org/studifrancesi/9255

DOI: 10.4000/studifrancesi.9255

ISSN: 2421-5856

\section{Editore}

Rosenberg \& Sellier

\section{Edizione cartacea}

Data di pubblicazione: 1 juin 2008

Paginazione: 200

ISSN: 0039-2944

\section{Notizia bibliografica digitale}

Gaudenzio Boccazzi, «François-René de Chateaubriand, Viaggio in America», Studi Francesi [Online], 154 (LII | I) | 2008, online dal 30 novembre 2015, consultato il 12 janvier 2021. URL: http:// journals.openedition.org/studifrancesi/9255 ; DOl: https://doi.org/10.4000/studifrancesi.9255

Questo documento è stato generato automaticamente il 12 janvier 2021.

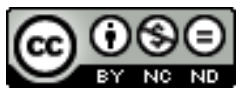

Studi Francesi è distribuita con Licenza Creative Commons Attribuzione - Non commerciale - Non opere derivate 4.0 Internazionale. 


\title{
François-René de Chateaubriand, Viaggio in America
}

\author{
Gaudenzio Boccazzi
}

\section{NOTIZIA}

FRANÇOIS-RENÉ DE CHATEAUBRIAND, Viaggio in America, traduzione e commento di Ada CORNERI, Torino, Edizioni Pietro Pintore, 2007, pp. 352.

1 Il Viaggio in America (del Nord) costituì il coronamento di un suo antico sogno; partì da Saint-Malo il 6 Maggio 1791 e fu di ritorno in Francia nel Gennaio 1792: il suo soggiorno nel Nuovo Mondo durò, effettivamente, dal 10 Iuglio al 10 Dicembre del 1791.

Questo Diario di Viaggio da lui ripreso, in vari modi, in molte delle sue opere successive, quando fu dato alle stampe, provocò forti impressioni ed alimentò anche precise contestazioni e numerose osservazioni critiche. Infatti, fin dalla sua pubblicazione, avvenuta nel 1827, si svilupparono subito numerose voci critiche che animarono un lungo dibattito sulla veridicità di questo diario, $o$, almeno, di quella parte che riferisce degli incontri dell'Autore con alcune importanti personalità americane. Tuttavia, il testo fornisce, effettivamente, un enorme materiale interessante ed utile alla ricerca e alla storia della criticha letteraria: si tratta di un vero filone storico-critico che, da una parte e dall'altra dell'Oceano Atlantico non ha cessato di animare uno specifico dibattito culturale, a partire dallo stesso anno della sua pubblicazione, prima negli Stati Uniti, per tutto l'Ottocento, e poi, fino a gran parte del Novecento, soprattutto in Francia.

3 L'opera che in questi ultimi mesi è stata pubblicata a Torino, in una pregevole traduzione italiana, merita tutta la nostra attenzione, non solo per il rinnovato interesse che, in questi ultimi decenni, si è manifestato per la Letteratura di Viaggio, ma anche per il suo valore intrinseco, di cui la Curatrice ha saputo rendere conto. 